\title{
Method development for the analysis of polybrominated diphenyl ethers, polychlorinated biphenyls, polychlorinated dibenzo- $p$-dioxins and dibenzo-furans in single extract of sediment samples
}

\author{
Hanxia Liu ${ }^{\mathrm{a}, \mathrm{b}}$, Qinghua Zhang ${ }^{\mathrm{a}}$, Maoyong Song ${ }^{\mathrm{a}}$, \\ Guibin Jiang ${ }^{a}$, Zongwei Cai ${ }^{a, b, *}$

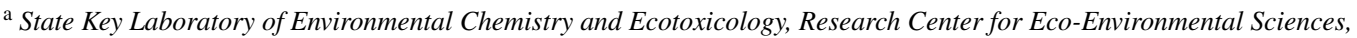 \\ Chinese Academy of Sciences, Beijing 100085, PR China \\ ${ }^{\mathrm{b}}$ Dioxin Analysis Laboratory, Hong Kong Baptist University, Kowloon, Hong Kong, China
}

Received 31 October 2005; received in revised form 29 November 2005; accepted 29 November 2005

Available online 6 January 2006

\begin{abstract}
A comprehensive method was developed for quantitative analysis of polybrominated diphenyl ethers (PBDEs), polychlorinated biphenyls (PCBs) and polychlorinated dibenzo- $p$-dioxins and dibenzo-furans (PCDD/Fs) in one single extract of environmental samples. The sample preparation procedure included two fractionation steps using silver nitrate silica chromatography to separate PBDEs from PCBs and PCDD/Fs and florisil column to separate PCBs from PCDD/Fs. Acidic silica, acidic alumina and gel permeation chromatography (GPC, for PCBs) or activated carbon column (for PCDD/Fs) were used for further clean-up. The sample extracts were analyzed by using high-resolution gas chromatography/highresolution mass spectrometry. The entire method was validated from the analysis of mixed standards of PBDEs, PCBs and PCDD/Fs $(n=3)$; the analysis of certified reference biota (WMF-01). The method was applied for the analysis of 10 sediment samples collected from Haihe River and Dagu Drainage River in Tianjin City. No significant PBDEs pollution was found in the areas.
\end{abstract}

(C) 2005 Elsevier B.V. All rights reserved.

Keywords: $\mathrm{PBDEs} ; \mathrm{PCBs} ; \mathrm{PCDD} / \mathrm{Fs} ; \mathrm{AgNO}_{3}$ silica gel chromatography; Sediments

\section{Introduction}

Polybrominated diphenyl ethers (PBDEs), polychlorinated biphenyls (PCBs) and polychlorinated dibenzo- $p$-dioxins and dibenzo-furans (PCDD/Fs) have been of great concern due to their toxicity and potential health risks [1-5]. However, most of the currently available methods involve two or three individual sample preparation procedures followed by instrument analysis, which is time and solvent consuming. Thus, a rapid and reliable procedure for the simultaneous sample preparation for PBDEs, PCBs and PCDD/Fs is needed.

Separation of PBDEs from PCBs and PCDD/Fs is difficult and vital in the simultaneous sample preparation procedure and consequent gas chromatography/mass spectrometry (GC/MS)

\footnotetext{
* Corresponding author. Tel.: +852 3417070; fax: +852 34117348 .

E-mail address: zwcai@hkbu.edu.hk (Z.Cai).
}

analysis because the compounds often have co-elution problem on various types of GC-column with the same isobaric ions [6-9]. Multi-layer silica column has been used to separate $\mathrm{PBDEs}$ from $\mathrm{PCBs}$ and $\mathrm{PCDD} / \mathrm{Fs}$. In the multi-layer silica column, silver nitrate silica was found to play an important role in the separation procedure. It was reported that PBDEs could not be separated from PCBs and PCDD/Fs by using the multilayer silica column if the layer of acidic silica was overloaded with sample extracts due to the severe matrix effect on separation efficiency [6]. In these cases, a new multi-layer silica column was needed to clean the sample prior to the separation of PBDEs, which not only affected the recovery but also spent much more time and solvent. In this study, investigation was conducted to use silver nitrate silica to replace the multiplelayer silica to separate PBDEs from PCBs and PCDD/Fs after the clean-up by individual acidic silica and acidic alumina column chromatography. Further clean-up of the PCBs and PCDD/Fs fractions were achieved by using GPC and active carbon col- 
umn chromatography, respectively. The method was validated through the analysis of mixed standards and certified reference tissue sample (WMF-01) and applied for the determination of PBDEs along with PCBs and PCDD/Fs in sediment samples collected from Haihe River and Dagu Drainage River in Tianjin City.

\section{Materials and methods}

\subsection{Chemicals}

All solvents were absolve grade and were purchased from Tedia. Silica gel $(0.063-0.100 \mathrm{~mm})$ was obtained from Merck. Bio-Beams SX-3 was purchased from Bio-Rad. Standard solutions of PCDD/Fs (1613-LCS (Labeled Compound Stock Solution), 1613-ISS $\left({ }^{13} \mathrm{C}-1,2,3,4-\mathrm{TCDD}\right.$ and ${ }^{13} \mathrm{C}-1,2,3,7,8$, 9-HxCDD Internal Standard Spiking Solution) and 1613-PAR (Native PCDD/Fs, Precision and Recovery Stock Solution)), PCBs (WP-LCS (WHO ${ }^{13}$ C-PCBs Surrogate Spiking Solution), WP-ISS (WHO ${ }^{13} \mathrm{C}-\mathrm{PCBs}$, Internal Standard Solution), MXP) and PBDEs $\left({ }^{13} \mathrm{C}\right.$-labeled MBDE-MXC, MBDE-139-IS) were obtained from Wellington Laboratories. Certified reference material WMF-01 (reference fish tissue for organic contaminant analysis) was also obtained from Wellington Laboratories. Ten sediment samples were collected from Haihe River and Dagu Drainage River in Tianjin City of China in November 15-16, 2003. Detailed sample collection and extraction procedures were described elsewhere $[10,11]$.

\subsection{Sample preparation and purification}

Freeze-dried environmental sediment samples were spiked with ${ }^{13} \mathrm{C}$-labeled surrogate standards prior to a 24-h Soxhlet extraction with 1:1 dichloromethane (DCM):hexane. After the extraction, acidic silica was added to remove lipid in the tissue samples. The extract was concentrated by using a rotary evaporator, and the residue was dissolved in $7 \mathrm{ml}$ hexane in the vial. Eight millilitres of concentrated sulphuric acid was added and the vial was shaked and then allowed to stand for an hour. The above extraction, concentration and acidic treatment steps were not needed during the development of the chromatographic clean-up procedure, for which a solution of mixed chemical standards was used. The organic layer in the vial was sequentially subjected to acidic silica gel, acidic alumina, silver nitrate $\left(\mathrm{AgNO}_{3}\right)$ silica $(10 \%, \mathrm{w} / \mathrm{w})$ for the separation of PBDEs from $\mathrm{PCBs}$ and PCDD/Fs and florisil for the separation of PCBs and PCDD/Fs. Activated carbon chromatography columns and gel permeation chromatography (GPC) were used for further cleanup of PCBs and PCDD/Fs, respectively. The activated carbon column was packed by using a glass pipette from bottom to top with glass wool, $0.15-0.2 \mathrm{ml}$ silica gel, $0.35-0.4 \mathrm{ml} 18 \%$ activated carbon/celite 545 mixture, $0.15-0.2 \mathrm{ml}$ silica gel and glass wool. The GPC was packed with pre-swollen and washed BioBeads SX-3 corresponding to $30 \mathrm{~g}$ dry material by using $1: 1$ DCM:hexane as the solvent. The eluted sample was collected in three fractions, which were concentrated to dryness. Then, ${ }^{13} \mathrm{C}$-labeled internal standards, WP-ISS (for PCBs), MBDE 139 (for PBDEs) and 1613-ISS (for PCDD/Fs), were added prior to the GC injection.

\subsection{Instrumental analysis}

The instrument analysis of PBDEs, PCDD/Fs and PCBs was performed on an Agilent 6890 gas chromatography coupled with an Autospec Ultima mass spectrometer operating with EI source in SIM mode. Two microliters of sample extract was injected with splitless mode into a DB-5MS fused silica capillary column $(60 \mathrm{~m} \times 250 \mu \mathrm{m}$ i.d. $\times 0.25 \mu \mathrm{m}$ film thickness) with helium as carrier gas. The details of the MS analysis and quality control are described in the EPA methods 1614-draft, 1613B and 1668A.

\section{Results and discussion}

\subsection{Method development}

\subsubsection{Separation of PBDEs from PCBs and PCDD/Fs by using silver nitrate silica column}

The key work of the method development for the analysis of PBDEs, PCBs and PCDD/Fs in one single sample was to separate PBDEs from PCBs and PCDD/Fs in the sample extract. Martínez et al. reported that separation of PBDEs from PCBs could be achieved by using neutral silica as absorbents [12]. Therefore, separation of PBDEs from PCBs and PCDD/Fs were investigated on neutral silica column $(9 \mathrm{~mm}$ i.d., $8 \mathrm{~cm})$. Different silica gel activation processes, baked at $170^{\circ} \mathrm{C}$ for at least $24 \mathrm{~h}$ and baked at $550{ }^{\circ} \mathrm{C}$ for $6 \mathrm{~h}$ and keep in $170^{\circ} \mathrm{C}$ for at least $24 \mathrm{~h}$, were investigated. The results showed that neutral silica under the current conditions could not effectively separate PBDEs from PCDD/Fs and PCBs. Neutral silica baked at $550{ }^{\circ} \mathrm{C}$ for $6 \mathrm{~h}$ is less adsorptive than the one baked at $170^{\circ} \mathrm{C}$. The different results of separation efficiency between our experiments and that reported by Martínez et al. may be due to the difference of characteristics of the silica sorbents or their preparation procedure.

$\mathrm{AgNO}_{3}$ silica was then selected for the separation of PBDEs from PCBs and PCDD/Fs. The results showed that the orders of elution depended on the levels of chlorination or bromination of the compounds, but in different patterns. For PCBs and $\mathrm{PCDD} / \mathrm{Fs}$, mono-CBs and 2,3,7,8-TCDD were the last eluted congeners, respectively; while mono-BDEs were first eluted out of the $\mathrm{AgNO}_{3}$ silica column among the PBDEs. Therefore, in order to separate PBDEs from PCBs and PCDD/Fs, the separation of BDE-28 from PCB-28 and 2,3,7,8-TCDD, which are the first or the last elution congeners among our target compounds, was the most difficult. Chromatograms of 2,3,7,8-TCDD/F, PCB-28 and BDE-28 in different fractions were presented in Fig. 1. As shown in Fig. 1, 100\% 2,3,7,8TCDF and PCB-28 were eluted in the first $80 \mathrm{ml}$ hexane, and $90 \%$ of $2,3,7,8$-TCDD was eluted in $90 \mathrm{ml}$ hexane, while BDE28 was only detected in the $6 \%$ DCM in hexane eluting solvent, indicating that a complete separation of PBDEs from PCBs and PCDD/Fs was achieved. Therefore, $100 \mathrm{ml}$ of hexane was selected to elute PCBs and PCDD/Fs, followed by $40 \mathrm{ml}$ of $6 \%$ DCM in hexane for the elution of PBDEs. 


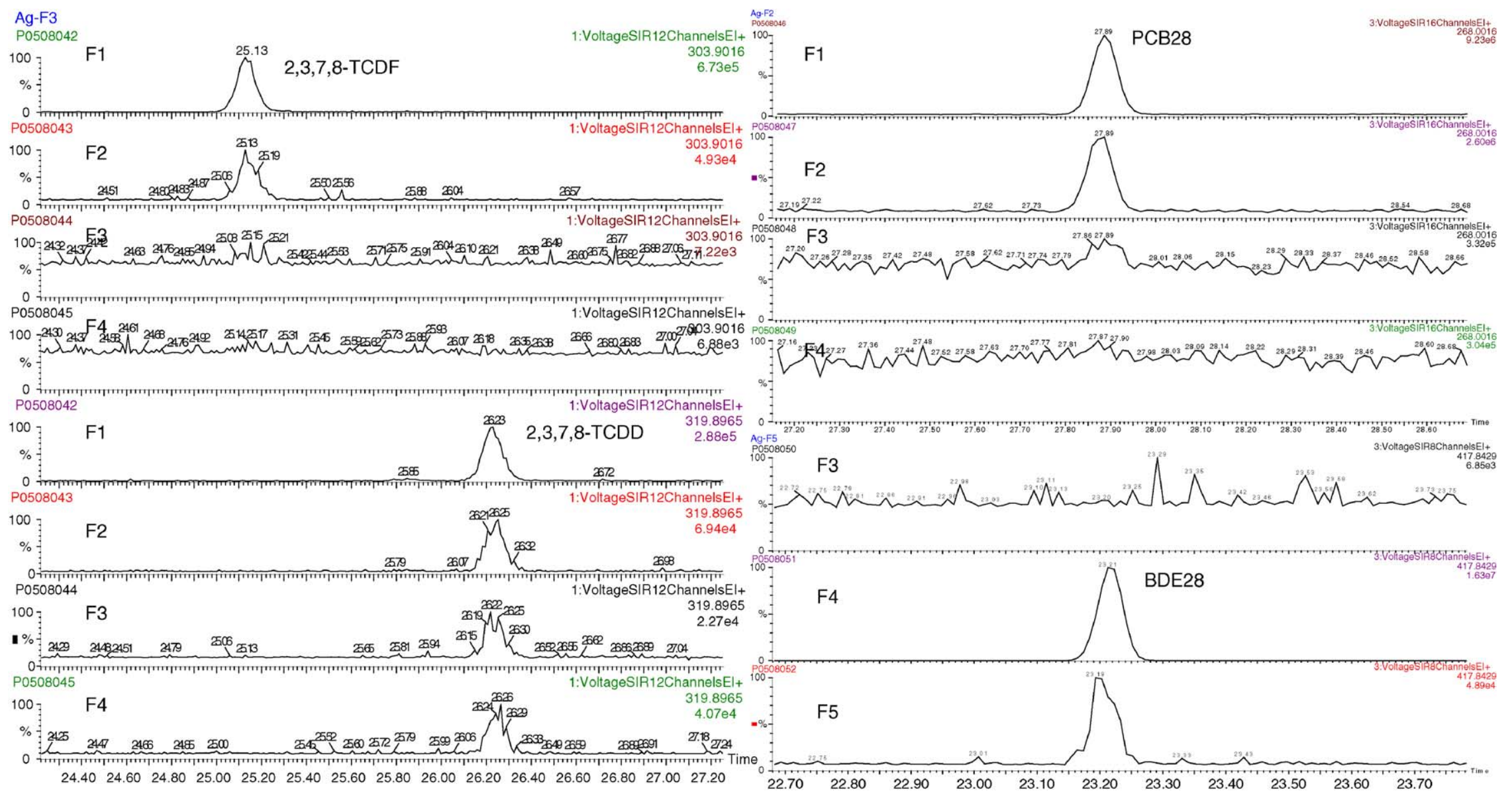

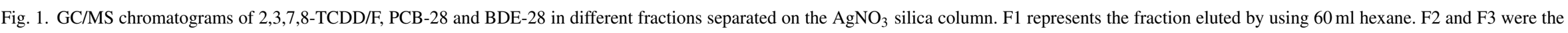
fractions eluted with additional 20 and $30 \mathrm{ml}$ hexane, respectively. F4 represents the fraction eluted by $40 \mathrm{ml} 6 \%$ DCM in hexane, and F5 was with additional $20 \mathrm{ml}$ of $6 \%$ DCM in hexane. 
Table 1

Recoveries and relative standard deviation (R.S.D.) ( $n=3)$ of PCBs, PCDD/Fs and PBDEs from the analysis of the standard mixture of 1613-LCS, WHO-LCS, MXP and MBDE-LCS

\begin{tabular}{|c|c|c|c|c|c|}
\hline Compounds & $\# 1$ & $\# 2$ & \#3 & Average & R.S.D. \\
\hline${ }^{13} \mathrm{C}-\mathrm{BDE}-15$ & 62 & 43 & 44 & 50 & 22 \\
\hline${ }^{13} \mathrm{C}-\mathrm{BDE}-28$ & 87 & 74 & 81 & 81 & 8 \\
\hline${ }^{13} \mathrm{C}-\mathrm{BDE}-47$ & 125 & 117 & 116 & 119 & 4 \\
\hline${ }^{13}$ C-BDE-99 & 79 & 79 & 78 & 79 & 1 \\
\hline${ }^{13} \mathrm{C}-\mathrm{BDE}-153$ & 88 & 87 & 84 & 86 & 2 \\
\hline${ }^{13} \mathrm{C}-\mathrm{BDE}-154$ & 98 & 98 & 98 & 98 & 0 \\
\hline${ }^{13} \mathrm{C}-\mathrm{BDE}-183$ & 66 & 62 & 61 & 63 & 4 \\
\hline IS ${ }^{13} \mathrm{C}-2378-\mathrm{TCDF}$ & 83 & 65 & 58 & 69 & 18 \\
\hline IS ${ }^{13} \mathrm{C}-12378-\mathrm{PeCDF}$ & 80 & 67 & 65 & 71 & 12 \\
\hline IS ${ }^{13} \mathrm{C}-23478-\mathrm{PeCDF}$ & 82 & 72 & 61 & 72 & 15 \\
\hline IS ${ }^{13} \mathrm{C}-123478-\mathrm{HxCDF}$ & 90 & 75 & 60 & 75 & 20 \\
\hline IS ${ }^{13} \mathrm{C}-123678-\mathrm{HxCDF}$ & 89 & 72 & 60 & 74 & 19 \\
\hline IS ${ }^{13} \mathrm{C}-234678-\mathrm{HxCDF}$ & 88 & 75 & 60 & 74 & 18 \\
\hline IS ${ }^{13} \mathrm{C}-123789-\mathrm{HxCDF}$ & 80 & 72 & 57 & 70 & 17 \\
\hline IS ${ }^{13} \mathrm{C}-1234678-\mathrm{HpCDF}$ & 78 & 73 & 61 & 71 & 13 \\
\hline IS ${ }^{13} \mathrm{C}-1234789-\mathrm{HpCDF}$ & 71 & 70 & 60 & 67 & 9 \\
\hline IS ${ }^{13} \mathrm{C}-2378-\mathrm{TCDD}$ & 67 & 63 & 53 & 61 & 11 \\
\hline IS ${ }^{13} \mathrm{C}-12378-P e C D D$ & 79 & 71 & 59 & 70 & 15 \\
\hline IS ${ }^{13} \mathrm{C}-123478-\mathrm{HxCDD}$ & 92 & 80 & 60 & 77 & 21 \\
\hline IS ${ }^{13} \mathrm{C}-123678-H x C D D$ & 89 & 81 & 57 & 76 & 22 \\
\hline IS ${ }^{13} \mathrm{C}-1234678-\mathrm{HpCDD}$ & 82 & 73 & 58 & 71 & 17 \\
\hline IS ${ }^{13} \mathrm{C}-\mathrm{OCDD}$ & 66 & 62 & 52 & 60 & 12 \\
\hline${ }^{13} \mathrm{C}-\mathrm{CB}-77$ & 100 & 88 & 94 & 94 & 6 \\
\hline${ }^{13} \mathrm{C}-\mathrm{CB}-81$ & 99 & 90 & 96 & 95 & 5 \\
\hline${ }^{13} \mathrm{C}-\mathrm{CB}-105$ & 80 & 90 & 100 & 90 & 11 \\
\hline${ }^{13} \mathrm{C}-\mathrm{CB}-114$ & 82 & 87 & 100 & 89 & 11 \\
\hline${ }^{13} \mathrm{C}-\mathrm{CB}-118$ & 66 & 84 & 93 & 81 & 17 \\
\hline${ }^{13} \mathrm{C}-\mathrm{CB}-123$ & 79 & 89 & 100 & 90 & 12 \\
\hline${ }^{13} \mathrm{C}-\mathrm{CB}-126$ & 76 & 79 & 90 & 82 & 9 \\
\hline${ }^{13} \mathrm{C}-\mathrm{CB}-156$ & 84 & 89 & 97 & 90 & 8 \\
\hline${ }^{13} \mathrm{C}-\mathrm{CB}-157$ & 85 & 89 & 100 & 91 & 8 \\
\hline${ }^{13} \mathrm{C}-\mathrm{CB}-167$ & 89 & 87 & 94 & 90 & 4 \\
\hline${ }^{13} \mathrm{C}-\mathrm{CB}-169$ & 90 & 88 & 96 & 91 & 5 \\
\hline${ }^{13} \mathrm{C}-\mathrm{CB}-189$ & 96 & 89 & 100 & 95 & 6 \\
\hline${ }^{13} \mathrm{C}-\mathrm{CB}-28$ & 34 & 60 & 72 & 56 & 35 \\
\hline${ }^{13} \mathrm{C}-\mathrm{CB}-52$ & 52 & 68 & 74 & 65 & 17 \\
\hline${ }^{13} \mathrm{C}-\mathrm{CB}-101$ & 70 & 72 & 80 & 74 & 7 \\
\hline${ }^{13} \mathrm{C}-\mathrm{CB}-153$ & 83 & 79 & 86 & 83 & 4 \\
\hline${ }^{13} \mathrm{C}-\mathrm{CB}-180$ & 65 & 84 & 87 & 79 & 15 \\
\hline${ }^{13} \mathrm{C}-\mathrm{CB}-194$ & 62 & 77 & 74 & 71 & 12 \\
\hline${ }^{13} \mathrm{C}-\mathrm{CB}-206$ & 61 & 76 & 83 & 73 & 16 \\
\hline${ }^{13} \mathrm{C}-\mathrm{CB}-209$ & 112 & 144 & 151 & 136 & 15 \\
\hline
\end{tabular}

\subsubsection{Further separation and purification of fractions containing PCBs and PCDD/Fs}

The separation of PCBs and PCDD/Fs was studied by using different chromatography columns with various solvent mixtures. Florisil chromatography column was found simpler and more efficient, which is accord with previous reports $[6,13,14]$. Eight centimetres of florisil was filled in the $9 \mathrm{~mm}$ i.d. glass column. Thirty-five milliliters of 6\% DCM in hexane was selected to elute PCBs, followed by $150 \mathrm{ml}$ of $100 \%$ DCM for the elution of PCDD/Fs.

A gel permeation chromatography column was used to remove high molecular weight interferences in the fraction of PCBs. After loading the sample extract containing PCBs, high molecular weight interferences were removed in the first $84 \mathrm{ml}$
Table 2

Data on PBDEs, PCBs and PCDD/Fs obtained from the analysis of the Certified Reference Material (WMF-01)

\begin{tabular}{|c|c|c|c|}
\hline Compounds & Measured (pg/g) & Certified (pg/g) & $Z$-score \\
\hline BDE-28 & 3243 & $3124 \pm 290$ & 0.41 \\
\hline BDE-47 & 123287 & $123200 \pm 24800$ & 0.00 \\
\hline BDE-99 & 37377 & $37500 \pm 220$ & 0.03 \\
\hline BDE-100 & 40733 & $35870 \pm 14500$ & 0.34 \\
\hline BDE-153 & 14165 & $17040 \pm 8000$ & 0.36 \\
\hline BDE-154 & 18535 & $19790 \pm 2880$ & 0.44 \\
\hline BDE-183 & 392 & $532 \pm 400$ & 0.35 \\
\hline CB-77 & 2425 & $2233 \pm 720$ & 0.27 \\
\hline CB-81 & 154 & $201 \pm 58$ & 0.80 \\
\hline CB-105 & 60933 & $49050 \pm 14200$ & 0.84 \\
\hline CB-114 & 4846 & $3523 \pm 1670$ & 0.79 \\
\hline CB-118 & 154207 & $130100 \pm 32500$ & 0.74 \\
\hline CB-123 & 4719 & $4233 \pm 2620$ & 0.19 \\
\hline CB-126 & 848 & $739 \pm 260$ & 0.42 \\
\hline CB-156 & 17472 & $14890 \pm 5020$ & 0.51 \\
\hline CB-157 & 4225 & $3488 \pm 870$ & 0.85 \\
\hline CB-167 & 9351 & $9750 \pm 3090$ & 0.13 \\
\hline CB-169 & 92 & $76 \pm 30$ & 0.54 \\
\hline CB-189 & 2263 & $2016 \pm 611$ & 0.40 \\
\hline 2378-TCDF & 13.75 & $13.10 \pm 4.9$ & 0.13 \\
\hline 12378-PeCDF & 0.07 & $1.53 \pm 1.4$ & 1.04 \\
\hline 23478-PeCDF & 7.61 & $7.15 \pm 2.2$ & 0.21 \\
\hline 123478-HxCDF & 0.27 & $0.86 \pm 1.0$ & 0.59 \\
\hline 123678-HxCDF & 0.30 & $0.51 \pm 0.7$ & 0.30 \\
\hline 234678-HxCDF & 0.31 & $0.68 \pm 1.2$ & 0.31 \\
\hline 123789-HxCDF & 0.05 & $0.25 \pm 0.4$ & 0.50 \\
\hline 1234678-HpCDF & 0.30 & $1.01 \pm 1.9$ & 0.37 \\
\hline 1234789-HpCDF & 0.03 & $0.30 \pm 0.5$ & 0.54 \\
\hline OCDF & 0.72 & $1.38 \pm 2.1$ & 0.31 \\
\hline 2378-TCDD & 14.39 & $13.10 \pm 4.4$ & 0.29 \\
\hline 12378-PeCDD & 3.01 & $2.72 \pm 1.3$ & 0.22 \\
\hline 123478-HxCDD & 0.03 & $0.22 \pm 0.3$ & 0.63 \\
\hline 123678-HxCDD & 0.77 & $0.88 \pm 0.4$ & 0.28 \\
\hline 123789-HxCDD & 0.03 & $0.27 \pm 0.4$ & 0.59 \\
\hline 1234678-HpCDD & 0.39 & $0.59 \pm 0.7$ & 0.29 \\
\hline OCDD & 4.83 & $3.91 \pm 6.2$ & 0.15 \\
\hline
\end{tabular}

of 1:1 DCM:hexane, and PCBs were then eluted with additional $30 \mathrm{ml}$ of 1:1 DCM:hexane. It was found that GPC was efficient for removing the chemicals that interfered with the quantification of PCBs, which is consist with the literature reports [15-17].

Further clean-up for the PCDD/Fs fraction was achieved by using the carbon column chromatography. The sample extract was loaded with 1:1 DCM:cyclohexane and the PCDD/Fs were eluted with $30 \mathrm{ml}$ toluene.

Table 3

Background contamination of PCBs and PBDEs in method blanks $(n=5)$

\begin{tabular}{lll}
\hline Congeners & Average (pg/sample) & R.S.D. (\%) \\
\hline PCB-77 & 0.21 & 17.5 \\
PCB-105 & 2.82 & 19.3 \\
PCB-118 & 6.30 & 17.8 \\
BDE-47 & 6.94 & 12.4 \\
BDE-99 & 3.43 & 20.5 \\
BDE-153 & ND & - \\
\hline
\end{tabular}


Table 4

Concentrations of PCBs, PCDD/Fs, and PBDEs detected in sediment samples from Haihe River and Dagu Drainage River (pg/g dw)

\begin{tabular}{|c|c|c|c|c|c|c|c|c|c|c|}
\hline Name & H1 & $\mathrm{H} 2$ & $\mathrm{H} 3$ & H6 & $\mathrm{H} 7$ & H8 & H9 & H10 & N1 & N3 \\
\hline BDE-15 & 28.4 & 40.3 & 37.4 & 50.2 & 19.5 & 50.0 & 829.8 & 363.7 & 1480.4 & 9985.6 \\
\hline BDE-17 & 2.7 & 2.0 & 5.3 & 5.3 & 2.3 & 9.8 & 3.3 & 1.6 & 31.7 & 7.4 \\
\hline BDE-28 & 12.6 & 10.1 & 28.8 & 16.9 & 8.1 & 28.9 & 17.2 & 6.7 & 168.1 & 201.3 \\
\hline BDE-47 & 45.1 & 67.8 & 158.5 & 30.3 & 24.7 & 69.7 & 17.4 & 8.2 & 756.4 & 23.0 \\
\hline BDE-49 & 14.4 & 13.2 & 40.0 & 19.7 & 9.1 & 30.4 & 10.3 & 4.0 & 281.3 & 9.6 \\
\hline BDE-66 & 10.4 & 8.6 & 22.0 & 8.1 & 6.9 & 18.4 & 2.5 & 1.0 & 88.5 & 3.1 \\
\hline BDE-71 & 0.7 & 0.5 & 1.1 & 1.2 & 0.4 & 2.0 & 0.3 & 0.1 & 2.3 & 0.3 \\
\hline BDE-77 & 2.3 & 1.7 & 3.6 & 2.1 & 1.4 & 5.7 & 0.5 & 0.2 & 13.3 & 0.5 \\
\hline BDE-85 & 1.4 & 2.5 & 1.8 & 1.9 & 2.0 & 3.3 & 0.4 & 0.1 & 40.4 & 1.8 \\
\hline BDE-99 & 31.2 & 59.9 & 183.7 & 25.5 & 29.2 & 26.5 & 8.8 & 4.2 & 983.1 & 15.8 \\
\hline BDE-100 & 7.9 & 22.4 & 43.4 & 6.0 & 5.0 & 5.4 & 2.8 & 1.1 & 198.3 & 4.7 \\
\hline BDE-119 & 0.4 & 0.4 & 0.8 & 0.3 & 0.2 & 0.9 & 0.1 & 0.1 & 0.6 & 0.4 \\
\hline BDE-126 & 6.4 & 5.0 & 8.0 & 5.9 & 1.6 & 16.9 & 0.6 & 0.3 & 12.3 & 10.0 \\
\hline BDE-138 & 3.2 & 1.9 & 4.1 & 2.5 & 2.0 & 7.7 & 0.9 & 0.6 & 9.8 & 2.5 \\
\hline BDE-153 & 18.9 & 29.9 & 1.2 & 29.4 & 24.6 & 18.4 & 4.1 & 2.1 & 308.1 & 6.6 \\
\hline BDE-154 & 7.0 & 16.0 & 19.0 & 9.2 & 4.9 & 4.9 & 2.0 & 1.0 & 113.7 & 2.4 \\
\hline BDE-183 & 49.9 & 19.1 & 61.0 & 137.9 & 48.0 & 64.2 & 18.6 & 5.3 & 487.5 & 26.5 \\
\hline Total-PBDEs & 242.9 & 301.3 & 619.5 & 352.3 & 189.8 & 362.9 & 919.5 & 400.4 & 4975.8 & 10301.7 \\
\hline CB-77 & 31.5 & 112.5 & 186.3 & 357.2 & 173.5 & 53.2 & 29.9 & 13.1 & 235.0 & 121.7 \\
\hline CB-81 & 1.3 & 1.4 & 5.8 & 19.0 & 1.8 & 2.6 & 0.6 & 0.3 & 14.7 & 2.3 \\
\hline CB-105 & 34.7 & 48.6 & 230.6 & 504.6 & 84.1 & 102.7 & 26.5 & 11.6 & 256.8 & 98.3 \\
\hline CB-114 & 2.2 & 2.4 & 11.1 & 14.7 & 2.3 & 4.2 & 1.3 & 0.7 & 17.4 & 3.5 \\
\hline CB-118 & 75.4 & 102.9 & 429.1 & 1094.0 & 145.9 & 159.0 & 99.5 & 45.9 & 407.4 & 633.9 \\
\hline CB-123 & 3.8 & 3.8 & 21.3 & 44.1 & 6.7 & 10.5 & 5.7 & 4.5 & 19.5 & 73.2 \\
\hline CB-126 & 2.9 & 4.6 & 8.1 & 31.6 & 5.1 & 11.5 & 5.0 & 1.7 & 15.6 & 30.6 \\
\hline CB-156 & 9.3 & 16.0 & 72.7 & 156.5 & 25.8 & 73.4 & 13.7 & 6.5 & 54.5 & 62.8 \\
\hline CB-157 & 3.0 & 4.8 & 16.5 & 53.8 & 7.3 & 36.7 & 5.5 & 2.3 & 15.0 & 29.8 \\
\hline CB-167 & 4.2 & 7.4 & 26.4 & 66.7 & 10.9 & 51.5 & 9.8 & 4.0 & 24.9 & 57.0 \\
\hline CB-169 & 0.7 & 1.0 & 1.4 & 8.5 & 1.4 & 4.0 & 0.8 & 0.3 & 22.6 & 2.7 \\
\hline CB-189 & 1.4 & 3.1 & 5.2 & 32.1 & 3.5 & 37.7 & 5.3 & 2.0 & 11.1 & 22.2 \\
\hline CB-28 & 381.0 & 568.4 & 3591.1 & 5009.1 & 1092.8 & 535.6 & 294.1 & 172.3 & 5767.1 & 456.5 \\
\hline CB-52 & 151.0 & 215.0 & 727.6 & 1831.1 & 342.5 & 244.7 & 166.4 & 121.0 & 1403.2 & 247.0 \\
\hline CB-101 & 89.8 & 114.8 & 560.4 & 1318.1 & 221.1 & 361.4 & 186.7 & 82.0 & 725.2 & 790.5 \\
\hline CB-138 & 90.5 & 117.3 & 622.9 & 1236.2 & 209.7 & 406.5 & 106.3 & 59.4 & 437.4 & 278.4 \\
\hline CB-153 & 87.5 & 118.8 & 610.4 & 1533.9 & 253.7 & 437.6 & 186.2 & 84.0 & 500.4 & 577.9 \\
\hline CB-180 & 28.0 & 43.7 & 163.1 & 712.0 & 96.9 & 444.6 & 100.0 & 38.0 & 205.6 & 313.5 \\
\hline CB-209 & 31.4 & 60.9 & 200.8 & 933.5 & 156.8 & 495.3 & 1522.8 & 242.3 & 225.5 & 7187.7 \\
\hline Total-PCBs & 1029.5 & 1547.4 & 7490.6 & 14956.4 & 2841.7 & 3472.5 & 2766.0 & 891.7 & 10358.7 & 10989.4 \\
\hline 2378-TCDF & 2.1 & 1.8 & 3.5 & 4.2 & 1.7 & 3.5 & 1.6 & 0.9 & 7.2 & 3.4 \\
\hline 12378-PeCDF & 2.1 & 2.0 & 0.9 & 1.7 & 0.5 & 5.5 & 1.3 & 0.3 & 8.6 & 4.9 \\
\hline 23478-PeCDF & 2.2 & 0.7 & 1.8 & 1.4 & 0.9 & 7.3 & 0.7 & 0.4 & 2.1 & 0.3 \\
\hline 123478-HxCDF & 3.6 & 6.6 & 6.5 & 13.6 & 4.7 & 76.5 & 17.9 & 7.4 & 37.8 & 125.3 \\
\hline 123678-HxCDF & 2.1 & 2.0 & 0.6 & 5.1 & 1.6 & 24.3 & 2.4 & 0.1 & 5.7 & 15.1 \\
\hline 234678-HxCDF & 1.5 & 1.9 & 0.9 & 3.9 & 1.4 & 21.5 & 3.2 & 1.4 & 6.2 & 35.0 \\
\hline 123789-HxCDF & 0.3 & 0.7 & 1.3 & 0.1 & 0.1 & 0.1 & 0.1 & 0.1 & 0.2 & 0.2 \\
\hline 1234678-HpCDF & 5.9 & 10.5 & 13.3 & 28.7 & 9.6 & 335.0 & 25.5 & 8.6 & 37.1 & 423.4 \\
\hline 1234789-HpCDF & 1.0 & 2.6 & 1.5 & 6.0 & 2.2 & 54.1 & 6.1 & 2.1 & 7.4 & 98.9 \\
\hline OCDF & 7.8 & 19.3 & 25.9 & 69.5 & 23.9 & 721.9 & 141.2 & 47.0 & 71.6 & 3119.6 \\
\hline 2378-TCDD & 0.4 & 0.7 & 0.9 & 0.5 & 0.1 & 0.5 & 0.5 & 0.3 & 0.1 & 1.8 \\
\hline 12378-PeCDD & 0.1 & 0.4 & 0.8 & 0.1 & 0.1 & 0.1 & 0.9 & 0.5 & 0.2 & 0.2 \\
\hline 123478-HxCDD & 0.4 & 0.9 & 0.9 & 2.7 & 0.8 & 11.0 & 17.9 & 5.7 & 12.3 & 74.4 \\
\hline 123678-HxCDD & 0.3 & 2.3 & 0.9 & 13.1 & 5.3 & 61.6 & 12.6 & 3.8 & 13.0 & 141.3 \\
\hline 123789-HxCDD & 0.6 & 1.4 & 0.9 & 7.5 & 2.0 & 32.9 & 7.0 & 2.3 & 9.8 & 41.7 \\
\hline 1234678-HpCDD & 8.7 & 60.0 & 69.6 & 199.8 & 57.9 & 1056.6 & 271.2 & 80.8 & 215.0 & 3091.8 \\
\hline OCDD & 63.4 & 333.1 & 326.7 & 984.1 & 317.2 & 5360.6 & 2928.6 & 992.3 & 2171.6 & 54147.4 \\
\hline Total-PCDD/Fs & 102.7 & 446.7 & 457.1 & 1342.0 & 429.8 & 7773.1 & 3438.6 & 1153.8 & 2605.8 & 61324.7 \\
\hline
\end{tabular}




\subsection{Method validation}

Method performance was evaluated by triplicate analyses of mixed standards including MBDE-MXC, 1613-LCS MXP and WP-LCS. The average recoveries and relative standard deviation (R.S.D.) of PBDEs, PCDD/Fs and PCBs are listed in Table 1. The results met the acceptance criteria specified in the US-EPA methods 1614-draft (25-150\%), 1613B (17-185\%) and 1668A (25-150\%).

CRM sample (WMF-01) was analyzed to validate the developed single analysis method for the PBDEs, PCBs and PCDD/Fs. The results were satisfied with $Z$-score $\leqq 1$ for all congeners. The recoveries of PBDEs, PCBs and PCDD/Fs were 91-110, 64-101 and 78-101\%, respectively, which again met the criteria specified in US-EPA method 1614-draft, 1668A and 1613B. Congener-specific concentrations of three groups of chemicals in WMF-01 are summarized in Table 2 and compared with the certified values.

\subsection{Quantitative analysis of sediment samples}

The method was applied for the analysis of 10 sediment samples collected from Haihe River and Dagu Drainage River in Tianjin City. Seventeen 2,3,7,8-subsituted chlorinated congeners of PCDD/Fs, 12 WHO toxic congeners of PCBs, 6 indicator PCBs (PCB-28, -52, -101, -138, -153 and -180) and PCB-209 as well as 17 PBDEs (BDE-15, -17, -28, -47, -49, -66, $-71,-77,-85,-99,-100,-119,-126,-138,-153,-154$ and -183$)$ were quantitatively determined. The background contamination of PCBs and PBDEs in method blanks is listed in Table 3. Concentrations of PBDEs, PCBs and PCDD/Fs determined in the sediment samples were listed in Table 4. Average recoveries for PCBs, PCDD/Fs and PBDEs are 45-92, 67-79 and 64-110\%, respectively, which met the criteria specified in US-EPA methods 1668A, 1613 and 1614-draft.

The obtained results indicated that sediments from Haihe River were contaminated with PBDEs, PCBs and PCDD/Fs. The concentrations of PBDEs, PCBs and PCDD/Fs in the sediments from Haihe River were $189.8-10301.7 \mathrm{pg} / \mathrm{g}$ dry weight (dw), $891.7-14956.4 \mathrm{pg} / \mathrm{g} \mathrm{dw}$ and $102.7-61324.7 \mathrm{pg} / \mathrm{g} \mathrm{dw}$, respectively. Serious PCDD/Fs pollution was found in Dagu Drainage River that is a municipal waste water discharging river. The detected profiles of PCDD/Fs show that the production of pentachlorophenol (PCP) or PCP-Na in this area may be the principal pollution source of PCDD/Fs, which is in accord with previously reported data [10]. The levels of PCBs and PCDD/Fs in site H10 were lower, compared to the results obtained from the previous sediment samples collected in July 2003. The difference in concentration may be due to the different sampling time because the samples analyzed in this study were collected during the flood season and the previously reported data referred to the samples collected in November. The contamination of PBDEs was investigated in this area for the first time. The results indicate that the contmination levels of PBDEs were low in Haihe River and Dagu Drainage River in Tianjin City.

\section{Conclusion}

A more convenient and stable sample preparation procedure has been developed to allow the determination of PBDEs, PCBs and PCDD/Fs in one single environmental sample. Silver nitrate silica was successfully used to separate PBDEs from PCBs and $\mathrm{PCDD} / \mathrm{Fs}$. The entire method was validated through the analysis of WMF-01 certified reference fish tissue. The performance of the method is satisfied. The method was applied to analyze sediment samples. Contamination levels of PBDEs were first reported for the sediment sample collection areas, along with $\mathrm{PCBs}$ and $\mathrm{PCDD} / \mathrm{Fs}$ levels compared with the data reported previously.

\section{Acknowledgements}

This work is jointly supported by National Basic Research Program of China (2003CB415001) and the State Hi-tech. Development Plan (2002AA601011). Jiang and Cai would also like to acknowledge the Distinguished Young Scholar Award of the National Science Foundation of China (20329701).

\section{References}

[1] E. Eljarrat, A. De La Cal, D. Larrazabal, B. Fabrellas, A.R. FernandezAlba, F. Borrull, R.M. Marce, D. Barcelo, Environ. Pollut. 136 (2005) 493.

[2] G. Falcó, A. Bocio, J.M. Llobet, J.L. Domingo, Food Chem. Toxicol. 43 (2005) 1713.

[3] A. Fernandes, S. White, K. D'Silva, M. Rose, Talanta 63 (2004) 1147.

[4] S. Litten, D.J. Mcchesney, M.C. Hamilton, B. Fowler, Environ. Sci. Technol. 37 (2003) 5502.

[5] C. Pirard, E. De Pauw, J.-F. Focant, J. Chromatogr. A 998 (2003) 169.

[6] H. Liu, Q. Zhang, Z. Cai, A. Li, Y. Wang, G. Jiang, Anal. Chim. Acta, in press.

[7] E. Eljarrat, A. de la Cal, D. Barcelo, J. Chromatogr. A 1008 (2003) 181.

[8] E. Eljarrat, D. Barcelo, Trends Anal. Chem. 23 (2004) 727.

[9] M. Alaee, in: R. Clement, B. Burk (Eds.), Proceedings of the Fourth Biennial International Conference on Monitoring and Measurement of the Environment, Toronto, 2002, p. 309.

[10] Q. Zhang, Study on characteristics of dioxin-like compounds in Taihu Lake and Haihe River basin in Tianjin, Ph.D.Thesis, Chinese Academy of Sciences, Beijing, 2004, p. 87.

[11] R. Yang, A. Lv, J. Shi, G. Jiang, Chemosphere 61 (2005) 347.

[12] A. Martínez, M. Ramil, R. Montes, D. Hernanz, E. Rubí, I. Rodríguez, R. Cela Torrijos, J. Chromatogr. A 1072 (2005) 83.

[13] E. Aries, D.R. Anderson, N. Ordsmith, K. Hall, R. Fisher, Chemosphere 54 (2004) 23.

[14] L. Ramos, L.M. Hernandez, M.J. Gonzalez, J. Chromatogr. A 759 (1997) 127.

[15] L.G.M.Th. Tuinstra, W.A. Traag, J.A. van Rhijn, P.F.V.D. Spreng, Chemosphere 29 (1994) 1859.

[16] R. Lega, G. Ladwig, O. Meresz, R.E. Clement, G. Crawford, R. Salemi, Y. Jones, Chemosphere 34 (1997) 1705

[17] K. Saito, A. Sjödin, C.D. Sandau, M.D. Davis, H. Nakazawa, Y. Matsuki, D.G. Patterson, Chemosphere 57 (2004) 373. 